\title{
Türkiye'de İkinci Ürün Soya (Glycine max L. Merrill) Yetiștirmeye Uygun Potansiyel Alanların Belirlenmesinde Coğrafi Bilgi Sistemleri Tabanlı Analitik Hiyerarși Süreç Tekniğinin Kullanımı
}

\author{
*Harun TORUNLAR', Ahmet Nedim NAZLICAN² \\ ${ }^{1}$ Tarla Bitkileri Merkez Araștırma Enstitüsü; Ankara, Türkiye \\ ${ }^{2}$ Doğu Akdeniz Tarımsal Araștırma Enstitüsü, Adana, Türkiye \\ *Sorumlu yazar e-posta (Corresponding author; e-mail): htorunlar@hotmail.com
}

\section{Öz}

$\mathrm{Bu}$ çalıșma ile, tarımsal arazilerin optimum kullanımlarına ve ürün planlamalarına yön vermek açısından, birim alandan birden fazla türden ürün alınmasına imkan sağlanması amacıyla, ikinci ürün soyanın yetișebileceği uygun potansiyel alanlar belirlenmiștir. Bir bölgede ürünlerin yetișebileceği uygun potansiyel alanların dağııımını etkileyen en önemli faktör, o ürünün yetișmesi için intiyaç duyduğu ekolojik kriterlerin birbirlerine göre yapacakları etkinin ağırlık oranları olmuștur. Yapılan bu çalıșmada, soyanın ikinci ürün olarak yetișmesi için ihtiyaç duyduğu ana kriterlerin (iklim, toprak, topoğrafya) ve bunlara ait alt kriterlerin (vegetasyon süresi, etkili sıcaklık toplamı, Temmuz ve Ağustos ayları ortalama sıcaklıkları, yükseklik, toprak derinliği ve arazi kullanım kabiliyet sınıfları) etkileri oranında sağlamıș oldukları ağırlıklarının hesaplanmasında, Coğrafi Bilgi Sistemleri (CBS) tabanlı Analitik Hiyerarși Süreç (AHS) tekniği uygulanmıș ve potansiyel uygunluk sınıfları belirlenmiștir. Yapılan değerlendirme sonuçlarına göre, çalıșma alanının \% 7.65'i (5 968013.35 hektar) çok uygun, \% 4.70’i (3 666170.55 hektar) orta uygun, \% 8.43'ü (6 584410.16 hektar) az uygun ve \% 79.22'si (61 839407.74 hektar) ise ikinci ürün olarak soya yetiștirilmesine uygun olmayan potansiyel alanlar olarak belirlenmiștir.

Anahtar Kelimeler: İkinci ürün soya, CBS, AHS, potansiyel uygun alanlar

\section{Use of GIS-based Analytical Hierarchy Process Technique in Determining Potential Areas Suitable for Double Crop Soybean (Glycine max L. Merrill) Cultivation in Turkey}

\section{Abstract}

The suitable lands for double crop soybean cultivation were determined by means of this study to shape the optimal use of the agricultural lands and crop planning to cultivate more than one crop from a unit of land. Most important factor governing the distribution of potentially suitable lands in a region was determined the weighted ratios of inter effects of ecological criteria required in crop production. GISbased Analytical Hierarchy Process (AHP) technique was applied to determine the weighted effects of the main criteria (i.e., climate, topography and soil) and their subcriteria (vegetation period, total effective temperature, average temperature of July and August, elevation, soil depth, land use capability classes) and potential suitablity classes were identified, in this research. According to the research results, $7.65 \%$ (5 968013.35 hectare) of the study area is found to be highly suitable, $4.70 \%$ (3 666170.55 hectare) to be modarete suitable, $8.43 \%$ (6 584410.16 hectare) to be less suitable, and $79.22 \%$ (61 839407.74 hectare) is not suitable for double crop soybean cultivation.

Keywords: Double crop soybean, GIS, AHP, potential suitable areas

\section{Giriș}

$\mathrm{G}$ ünümüzde tarım yapılan arazilerin gittikçe daralması, insan ve hayvan beslenmesinde önemli yer alan gıdalara olan intiyacı daha fazla öne çıkarmaktadır. Daralan tarım arazilerindeki ürün kayıplarını telafi edebilmek için, mevcut tarım arazilerinin optimum kullanımını sağlayarak, birim alandan fazla çeșitlilikte ürün alınması gerekmektedir. Bu da farklı ekolojik özelliklere sahip ülkemiz arazileri için, ikinci ürün yetiștirilmesini zorunlu kılmaktadır.Değerli bir besin maddesi olan soyanın, hem insan beslenmesindeki, hem 
de hayvan beslenmesindeki önemi büyüktür. Yağı alındıktan sonra geriye kalan küspesi, insan ve hayvan besini olarak kullanılmaktadır. Önemli bir baklagil bitkisi olan soya, köklerinde yașayan Rhizobium bredy japonicum bakterisi sayesinde havanın serbest azotunu toprağa bağlamaktadır. Bu nedenle hem kendisinden sonra ekilecek bitkiye azotça zengin bir tarla bırakmakta, hem de kendi intiyacı olan azotu karșılamaktadır (Arıoğlu, 2013). Saplarının toprakta kolay parçalanabilmesinden dolayı, toprağın organik maddesinin artırımasını sağlamaktadır. (Engin ve Arıoğlu, 1982). Dünya'da yenilebilir bitkisel yağ üretiminin \%30-35'ni soya karșılamaktadır (Mounts, 1987). Bu yüzden dünya'da en fazla üretimi yapılan baklagil bitkisi soyadır (Herridge ve Danso, 1995).

Ülkemizde ise, 2015 yılı tarım istatistikleri verilerine göre; soya ekim alanımı 343.178 da, soya üretimimiz ise 150 bin ton olmuștur (TUIK, 2015). Ülkemiz soya açısından iç piyasadaki talebi karșılayamamasından dolayı ithalatçı ülke konumunda olup, 2012 yılı verilelerine göre yıllık 1.195 bin ton soya ithalatı gerçekleștirmiștir.

Soyanın geniș bir adaptasyon kabiliyetine sahip olması, yaz periyodunun uzun geçtiği bölgelerde ikinci ürün olarak yetiștirilmesine imkan sağlamaktadır (Manuel, 1988). Ülkemizde, kıșlık yetiștirilen bitkilerden, özellikle buğday ve arpanın hasadından sonra, ikinci ürün olarak soya bașarıyla yetiștirilebilmektedir. Ayrıca, kıșlık mercimek, turfanda patates, kıșlık kolza gibi kısa vejetasyon süreli diğer kıșlık ürünlerin ardından da soyayı yetiștirmek mümkündür. 15-20 Haziran tarihlerine kadar hasadı bitirilebilen tüm kıșlık ürünlerden sonra, ikinci ürün soyaya uygun vejetasyon süresi kalabilmektedir.

İklim, toprak ve topoğrafya bakımından farklı ekolojik yapıları bünyesinde bulunduran ülkemizde, soyanın insan ve hayvan beslenmesindeki önemi göz önüne alındığında, yaygın olarak ekilebilmesi ve ülke ekonomisinde önemli bir yere sahip olabilmesi açısından, bu bitkinin öncelikle, ekolojik isteklerine ait kriterlerin ortaya konularak, yetiştirilebilecek potansiyel alanlarının belirlenmesi gerekmektedir. Ürünlere ait potansiyel alanların belirlenmesi çalıșmalarında, fazla sayıdaki ekolojik kriterlere ait veri setlerinin bir arada toplanması, bu verilerin ișlenmesi ve kullanılabilir çıktılar halinde üretilmesine sağladığı katkıdan dolayı Coğrafi Bilgi Sistemleri (CBS) teknolojisi yaygın olarak kullanılmaktadır. CBS tabanlı yaklașımlar, ürün isteklerine ait fazla sayıda kritere yönelik mekansal analizlerin yönetimi ve karar alınmasında yardımcı olabilmektedir (Mendas, 2007).

Ürünlere yönelik yetiştirilebilir potansiyel alanların belirlenmesine etki eden ekolojik kriterlerin, kendi arasında sağlamıș oldukları etki oranlarının belirlenmesinde, CBS tabanlı Analitik Hiyerarși Süreç (AHS) tekniği bașarılı bir șekilde uygulanabilen bir tekniktir (Prakash, 2003). Araștırmacılara farklı alanlarda kullanım imkanı sağlayan AHS tekniği, özellikle ürün yetiștirilmesi için arazi uygunluğunun belirlenmesi çalıșmalarında kullanılması kaçınılmaz, çok kriterli bir karar verme tekniğidir (Malczewski, 2004; Malczewski,2006; Mendas ve Delali, 2012).

He ve ark.'nın (2011) Çin' de yazlık ve kıșlık soyanın yetișebileceği potansiyel uygun alanların belirlenmesine yönelik yapmıș oldukları çalıșmada, CBS tabanlı olarak ürüne yönelik çok kriterli bir değerlendirme yaparlarken, kriterlere (topoğrafya, toprak ve iklim) ait ağırlık puanlarının belirlenmesinde, AHS tekniğini kullanmıșlardır. Yapmıș oldukları değerlendirmede, çalıșma alanının yazlık ve kıșlık soya için potansiyel uygunluk sınıflamasını çok yüksek, yüksek, orta, düșük ve çok düșük uygunluk sınıfları olarak elde etmișlerdir.

Dengiz ve Sarıoğlu'nun (2013) Samsun ili Bafra ilçesine ait Dedeli ve Çetinkaya köyleri ve yakın çevresinin tarımsal yönden arazi uygunluk değerlendirmesi çalışmalarında, araziye ait toprakların fiziksel (eğim, bünye, derinlik ve drenaj) ve kimyasal $\left(\mathrm{pH}, \mathrm{Ec}, \mathrm{CaCO}_{3}\right.$ , verimlilik) özelliklerine ait çok fazla kritere ait ağılık puanlarının hesaplanmasında doğrusal kombinasyon yöntemine ait AHS tekniğini kullanmıșlardır. Yapmıș oldukları uygunluk değerlendirmesinde, eğim kriteri için 0.233 , drenaj kriteri için 0.162 , bünye kriteri için 0.157 , $\mathrm{pH}$ kriteri için 0.141 , derinlik kriteri için 0.103 , EC kriteri için 0.100 , verimlilik kriteri için 0.044 
ve kireç kriteri için ise 0.008 ağırlık puanlarını hesaplamıșlardır.

Bu çalıșmada, tarımsal arazilerin optimum kullanımları, birim alandan birden fazla türden ürün alınması ve ürün planlamalarına yön verilmesi açısından, ikinci ürün olarak soyanın yetișebileceği potansiyel alanlar, CBS tabanlı AHS tekniğine göre belirlenmiștir.

\section{Materyal ve Yöntem}

\section{Materyal}

Bu çalıșma, bitkisel üretim planlamalarına yön vermek açısından, ülkesel bir ölçekte yürütülmüștür. Çalışmanın yürütüldüğü alan; dünya üzerindeki genel konumu itibariyle $35^{\circ} .40^{\prime}-42^{\circ} .06^{\prime}$ kuzey paralelleri ile $25^{\circ} .40^{\prime}$ $44^{\circ} .48^{\prime}$ doğu meridyenleri arasında yer almakta olup, uluslararası sınırları ve sahil șeridi ile ayrılmıș tüm alanlarının toplamı yaklașık olarak 780.580 km²'dir (ISO 3166-1) (Șekil 1).

Farklı topoğrafik özelliklere sahip olan çalıșma alanının, deniz seviyesinden olan ortalama yüksekliği 1132 metre'dir. Subtropikal kușakta yer alan çalıșma alanında, büyük bir iklim bölgesi olan Akdeniz iklimi hakimdir (Türkeș, 2000). Topoğrafyanın çok değișken olması, üç tarafının denizlerle çevrili olması ve yükseltilerin batıdan doğuya doğru artması, çalıșma alanı içinde birbirinden farklı iklim tiplerinin görülmesine neden olmaktadır. Yedi farklı coğrafik bölgeye ayrılan alanın, ekolojik (iklim, toprak, topoğrafya vb.) farklılıklara bağlı olarak yetiștirilen ürün çeșitliliği çok fazla olup, tarıma ayrılan alanlar toplam alanının üçte birini olușturmaktadır.

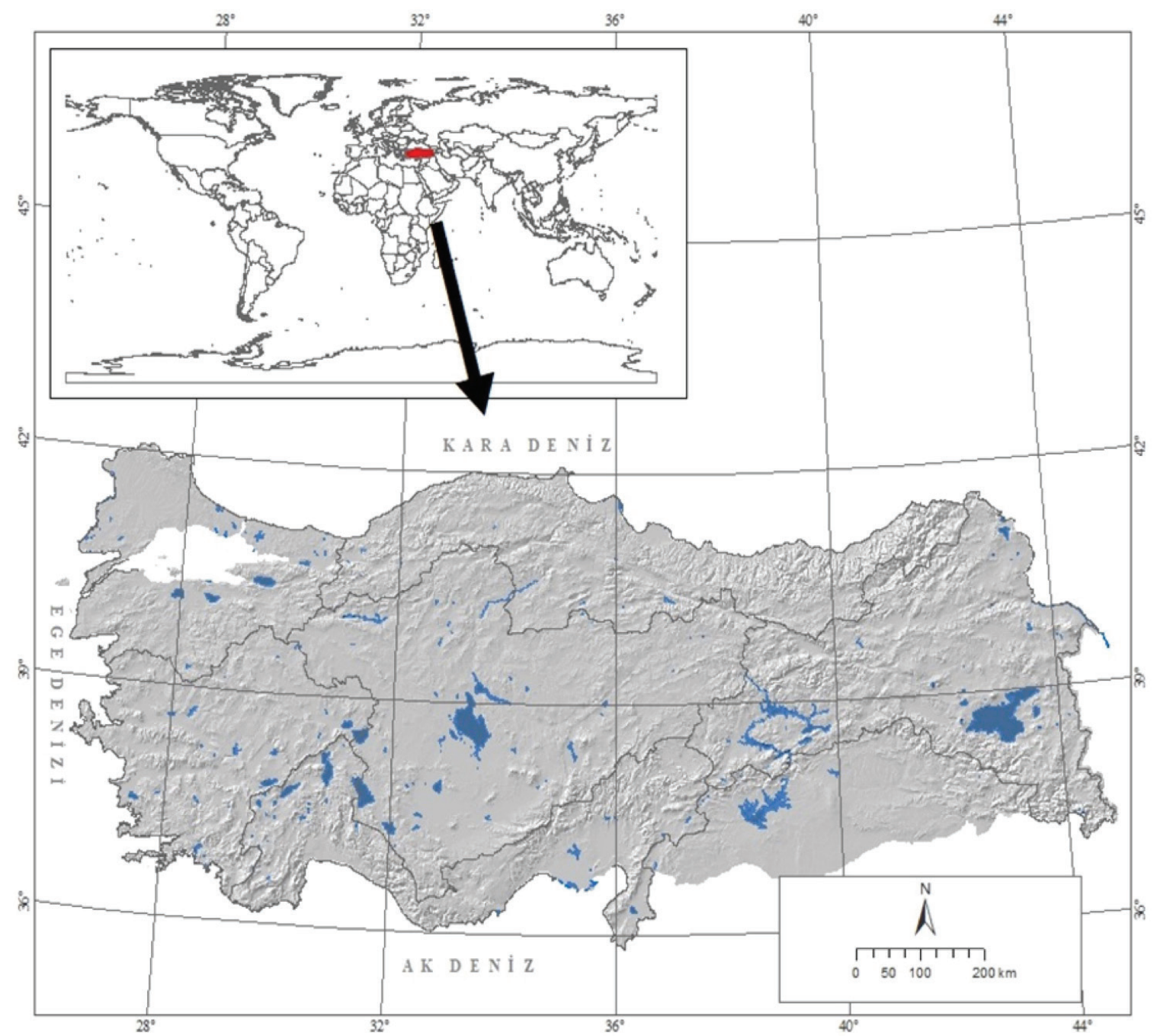

Șekil 1. Çalıșma alanı

Figure 1. Study area 


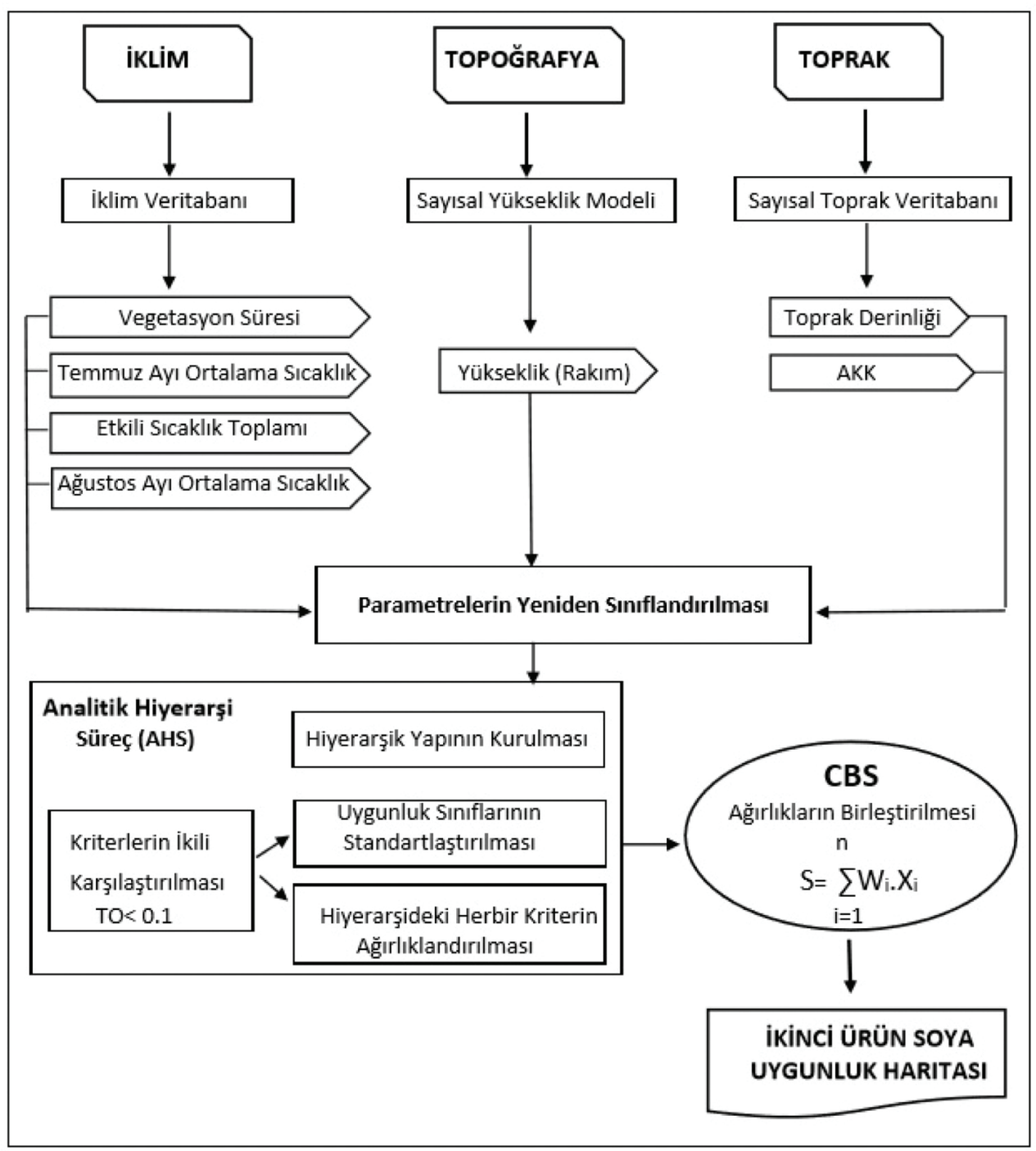

Șekil 2. Çalıșmada takip edilen yöntemin iș akıș șeması

Figure 2. Flowchart of the methodology followed in the study

Bu çalıșmada, ikinci ürün olarak soyanın yetiștirilebilmesi için, potansiyel uygun alanların belirlenmesinde etkili olabilecek çok sayıdaki veri seti, çalıșmanın materyali olarak kullanılmıștır. Bu veri setleri; iklim, topoğrafya ve toprak gibi ana kriterler içerisinde bölgesel değișkenlikler gösteren ve karmașık yapıda özelliklere sahip alt kriterlerden olușmaktadır.

\section{iklim Veri Seti}

$\mathrm{Bu}$ veri seti, Meteoroloji Genel Müdürlüğünden (MGM) temin edilen, çalıșma alanı içerisinde 270 adet büyük iklim istasyonunun 1975-2012 yılları arası kayıtları tutulmuș olan, iklim alt parametreleri verilerinin bir araya getirilmesinden elde edilen veritabanından olușmaktadır. İçeriğinde fazla sayıda iklim değișkenleri bulunduran bu veritabanı kullanılarak, ikinci ürün soyanın yetiștirilmesinde etkili olan vegetasyon süresi, etkili sıcaklık toplamı, Temmuz ve Ağustos ayları ortalama sıcaklık alt kriterleri elde edilmiștir. Alt kriterlerin elde edilmesinde, istasyon bazlı noktasal tabanlı verilerin çalıșma alanına yayılmıș yüzey dağılımları için Climap Pertziger ve De Pauw (2002) programı kullanılarak, Hutchinson (1995) interpolasyon metodu uygulanmıștır.

\section{Topoğrafik Veri Seti}

$\mathrm{Bu}$ veri setinde, topoğrafyanın dijital gösterimi olarak adlandırıan, 90 metre uzaysal çözünürlüğe sahip SRTM (Shuttle Radar Topography Mission) Sayısal Yükseklik Modeli 
(SYM) verisi kullanılmıștır (Farr, 2000). Yersel çözünürlüğü $1 / 250.000$ ölçekli olan bu veri modeli, bir arazi yüzeyini en iyi temsil eden düzenli, düzensiz aralıklarla yapılmıș çok sayıda yükseklik ölçümünden olușmaktadır. Raster ve grid veri yapısına sahip olması, SYM'nin ișlenmesini, hesaplamalarda etkin kullanımını kolaylaștırmaktadır (Martz, 1992). Bu veri seti, soyanın ikinci ürün olarak yetiștirilmesindeki yükseklik intiyacının karșılanması amacıyla kullanılmıștır.

\section{Toprak Veri Seti}

Toprak veri seti olarak, sayısal vektör formatındaki ülkesel toprak veri tabanı kullanılmıștır. 1/25 000 ölçekli bu veri seti, mülga Köy Hizmetleri Genel Müdürlüğü (KHGM) tarafından üretilmiş ülkesel boyutlu tek toprak verisidir. Bu veri seti, toprak grupları, eğim derinlik kombinasyonları, erozyon dereceleri, drenaj bünye kombinasyonları, arazi tipleri, șimdiki arazi kullanım șekilleri gibi bir çok bilgiyi yapısında bulundurmaktadır. İkinci ürün soya için bu veri setinin toprak derinliği ve arazi kullanım kabiliyet sınıfları bilgileri alt kriterler olarak kullanılmıștır.

\section{Yöntem}

İkinci ürün olarak soyanın uygun alanlarda yetiştirilmesinin belirlenmesine yönelik yapılan bu çalışmada, ürünün intiyaç duyduğu istekleri karşılayacak birden fazla sayıda kriter kullanılmıştır. Ana kriterler (İklim, toprak ve topoğrafya) ve bunların alt kriterleri olan, vegetasyon süresi, Temmuz ve Ağustos ayları ortalama sıcaklıklar, etkili sıcaklık toplamı (EST), yükseklik, arazi kullanım kabiliyet sınıfları (AKK) ve toprak derinlikleri verilerinin birlikte değerlendirilmesine yönelik uygulanan yöntemin iș akıș șeması Șekil 2'de verilmiștir.

Yönteme göre; ikinci ürün olarak soyanın intiyaç duyduğu her bir alt kriter için uzman görüșleri doğrultusunda çalıșma alanının karakteristik özelliklerini temsil eden ekolojik alt kriter sınıfları belirlenmiștir. Alt kriterlerin aynı ölçekte değerlendirilmesini sağlamak amacıyla

Çizelge 1. Alt kriter sınıf ve ağılık puanları

Table 1. Subcriteria classes and their weighted values

\begin{tabular}{lccc}
\hline Alt Kriterler & Alt Kriter Sınıfları & Uygunluk Sınıfları & $\begin{array}{c}\text { Alt Kriter Ağırlık } \\
\text { (uygunluk) Puanları }\end{array}$ \\
\hline & $>110$ & $\mathrm{~S} 1$ & 4 \\
Vegetasyon Süresi (Gün) & $100-110$ & $\mathrm{~S} 2$ & 3 \\
& $90-100$ & $\mathrm{~S} 3$ & 2 \\
& $<90$ & $\mathrm{~N}$ & 1 \\
Temmuz Ayı Ortalama. & $>25$ & $\mathrm{~S} 1$ & 4 \\
Sıc.(Co) & $22-25$ & $\mathrm{~S} 2$ & 3 \\
& $20-22$ & $\mathrm{~S} 3$ & 2 \\
Ağustos Ayı Ortalama & $<20$ & $\mathrm{~N}$ & 1 \\
Sıc. (Co) & $>25$ & $\mathrm{~S} 1$ & 4 \\
& $22-25$ & $\mathrm{~S} 2$ & 3 \\
Etkili Sıcaklık Toplamı ( & $20-22$ & $\mathrm{~S} 3$ & 2 \\
10 Co) & $<20$ & $\mathrm{~N}$ & 1 \\
& $2250-2000$ & $\mathrm{~S} 1$ & 4 \\
& $2000-1500$ & $\mathrm{~S} 2$ & 3 \\
Yükseklik (m) & $<1500$ & $\mathrm{~S} 3$ & 2 \\
& $0-600$ & $\mathrm{~N}$ & 1 \\
Arazi kullanım kabiliyet & $600-800$ & $\mathrm{~S} 1$ & 4 \\
Sınıfları (AKK) & $800-1100$ & $\mathrm{~S} 2$ & 3 \\
& $>1100$ & $\mathrm{~S} 3$ & $\mathrm{~N}$ \\
Derinlik (cm) & $\mathrm{I}$ & $\mathrm{S} 1$ & 1 \\
& $\mathrm{II}$ & $\mathrm{S} 3$ & $\mathrm{~N}$ \\
\hline
\end{tabular}


Çizelge 2. AHS tekniği ikili karșılaștırma ölçeği (Satty, 1980)

Table 2. The AHS scales for paired comparisons

\begin{tabular}{ll}
\hline Sayısal değer & Tanım \\
\hline 1 & Öğeler eșit derecede öneme sahiptir. \\
3 & 1. ölçüt 2.'ye göre biraz daha önemlidir. \\
5 & 1. ölçüt 2.'ye göre fazla önemlidir. \\
7 & 1. ölçüt 2.'ye göre çok fazla önemlidir. \\
9 & 1. ölçüt 2.'ye göre olası en kuvvetli öneme sahiptir. \\
$2,4,6,8$ & Iki yakın ölçek arasındaki ara değerdir. Uzlașma gereken durumlarda \\
& kullanımaktadır. \\
\hline
\end{tabular}

sınıflar standart hale getirilerek alt kriter ağırlık (uygunluk) puanları atanmıștır (Çizelge 1).

Değerlendirmeye alınan kriterlerden hem ana kriterlerin hem de alt kriterlerin kendi aralarında soyanın yetișmesi üzerinde, farklı düzeylerde etkileri bulunmaktadır. Her bir kriterin etki oranları, birbirlerine eșit olamayacağı için, kriterlerin birbirlerine göre önemleri göz önünde bulundurularak ağırlık puanları hesaplanmıștır.

Kriterler arası etki oranlarını ifade eden bu ağırlık puanları hesaplanırken, birden fazla çok kriterli yöntemlerden biri olan, Ağırlıklandırılmıș Doğrusal Kombinasyon yöntemine ait Analitik Hiyerarși Süreci (AHS) tekniği kullanılmıștır.

Bu teknik Saaty (1980) tarafından geliștirilmiș olup, karmașık yapıdaki çok fazla kritere sahip karar verme problemlerinin çözümünde kullanılmaktadır. Grup olarak alınan kararların belirli bir sistematik ve mantık yaklașımı içinde değerlendirilmesini sağlamaktadır. AHS, karar vericilerin karmașık problemleri, problemin ana hedefi, kriterleri, alt kriterler ve alternatifleri arasındaki ilișkiyi gösteren bir hiyerarșik yapıda modellemelerine olanak verir. Bu tekniğin en önemli özellikleri ise, karar vericinin hem kantitatif (objektif) hem de kalitatif (sübjektif) düșüncelerini karar sürecine dahil edebilmesi, uygulanmasının kolay ve esnek olması, elde edilen sonuçlarının tutarlıı̆̆ının kontrol edilebilmesi, anlașılabilir ve yorumlanmasının basit olmasıdır (Yılmaz ve ark., 2004). Bu tekniğin en önemli yapı tașı, kriterlerin birbirlerine göre önem dereceleri göz önüne alınarak ikili karșılaștırılmalarıdır.

Bu ikili karșılaștırmalardan yararlanarak bir düzeydeki her bir kriterin bir üst düzeydeki yerel öncelikleri hesaplanır (Büyükyazıcı, 2000). Elde edilen matrislerde ikili karșılaștırma sonuçlarını sayısal değerlere dönüștürmek için Saaty (1980) tarafından geliștirilen, 1-9 ölçeği kullanılmaktadır (Çizelge 2).

Bu çalıșmada, değerlendirmeye alınan ana ve alt kriterler için Analitik Hiyerarși Süreci tekniği kullanarak kriterlere ait etki oranlarını (ağırlık puanları) hesaplarken;

I- Öncelikle kriterler arası ikili karșılaștırma matrisi olușturulmuștur. Bu matris $n \times n$ boyutlu bir matristir ve matrisin köșegeni üzerindeki matris bileșenleri 1 değerini almaktadır.

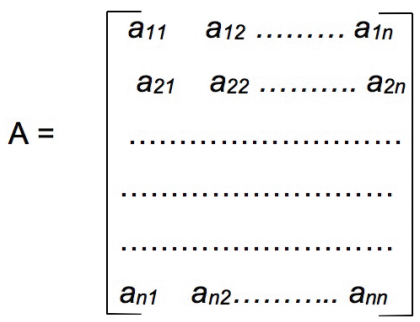

Burada;

A, ikili karșılaștırmalar matrisi; aij, hiyerarșinin bir üst düzeyindeki elemana göre, i elemanının j elemanına göre önemi $(i, j=1,2, \ldots, n)$ 'dir.

Karșılaștırma, kriterlerin birbirlerine göre sahip oldukları önem değerleri dikkate alınarak ikili ve karșılıklı yapılmaktadır. Karșılaștırma matrisinin köșegeni üzerindeki bileșenler $i=j$ olduğunda, yani "eșit derecede öneme sahip" olduğunda, ilgili kriter kendisi ile karșılaștırıldığı için 1 değerini almaktadır. Karșılaștırmalar, matrisin tüm değerleri 1 olan köșegeninin üstünde kalan değerleri için yapılır. Köșegenin altında kalan bileșenler için ise, așağıdaki ifade kullanılmaktadır. 


$$
\begin{aligned}
& a_{j i}=1 / a_{i j} \\
& a_{i j}>0(i, j=1,2,3 \ldots \ldots n)
\end{aligned}
$$

II- A matrisinin olușturulmasından sonra, ikili karșılaștırması yapılan kriterler için öncelik vektörü (W) (etki oranı veya ağırlıklı puanları) hesaplanmıștır. Yapılan bu hesaplamaya AHS'de sentezleme adı verilmektedir. Sentezleme yapılırken;

a) İkili karșılaștırmalar matrisinin her bir sütunundaki değerler toplanır.

b) İkili karșılaștırmalar matrisindeki her bir eleman, bulunduğu sütunun toplam değerine bölünür.

$\mathrm{Bu}$ ișlem sonucunda elde edilen matrise normalize edilmiș ikili karșılaștırmalar matrisi denir. Normalize edilmiș ikili karșılaștırmalar matrisindeki sütunların her birinin toplam değeri 1'e eșit olmaktadır.

c) Normalize edilmiș ikili karșılaștırmalar matrisinin her bir satırındaki elemanların, aritmetik ortalaması hesap edilir.

III-İkilikarșılaștırmalarmatrisiolușturulurken, kriterler arası yapılan ikili karșılaștırmalar subjektif temellere dayandığı için yanılgılar veya tutarsızlıklar ortaya çıkabilmektedir. Yapılan bu ikili karșılaștırmaların tutarlı olup olmadığını ölçmek için, AHS tekniğinde Tutarlılık Oranı (TO) kullanılmaktadır.

İkili karșılaștırma yargılarının tutarlıığını ölçmek için, Saaty tarafından önerilen ve üst limiti 0.10 (\%10) olan bir tutarlılık oranı (consistency ratio) kullanılmaktadır (Saaty, 1980). Hesaplanan tutarlılık oranı, 0.10'un altında bir değer ise, ikili karșılaștırmaların tutarlılık sergilediği ve değerlendirmenin devam edebileceği, eğer bu oran 0.10'un üstünde ise ikili karșılaștırmaların tutarsızlığı kabul edilmektedir. Bu durumda ikili karșılaștırmalar gözden geçirilerek, tutarlılık oranının düșürülmesi gerekmekte, aksi takdirde problemin yeniden kurulması ve sürecin baștan ele alınması gerekmektedir. (Armacost, 1994).

Tutarlılık oranının kontrolü yapılırken; İkili karșılaștırmalar matrisi (A) ile, öncelik vektörü (W) çarpılarak ağırlıklandırılmıș toplam vektör adında yeni bir vektör olușturulmuștur. $\mathrm{Bu}$ vektörün her bir elemanı buna karșılık gelen öncelik değerine bölünerek, elde edilen değerlerin aritmetik ortalamalarından maksimum özdeğer $\left(\lambda_{\text {max }}\right)$ hesaplanmıștır. Eleman sayısına bağlı olarak maksimum özdeğer kullanılarak aşağıdaki eşitlik yardımıyla ikili karşılaştırma matrisi (A) için, Tutarlıık İndeksi (TI) oluşturulmuştur.

$$
\mathrm{Ti}=\frac{\left(\lambda_{\max }-n\right)}{(n-1)}
$$

$n=$ karșılaștırılan elemanların sayısı

Hesaplanan tutarlılık indeksi yardımıyla tutarlılık oranı değeri, așağıdaki bağıntı kullanılarak elde edilmiștir.

$$
\begin{aligned}
& \mathrm{TO}=\frac{\mathrm{TI}}{\mathrm{RI}} \\
& T i=\text { Tutarlılık indeksi } \\
& R I=\text { Rastgele indeks }
\end{aligned}
$$

Rastgele indeks, rastgele üretilen ikili karșılaștırma matrislerinin ortalama tutarlılık indekslerini İfade etmekte olup, eleman sayısına bağlı olarak Çizelge 3'teki değerleri almaktadır.

Coğrafi bilgi sistemleri teknikleri kullanılarak, kriterlere ait uygunluk puanları,

Çizelge 3. Tutarlılık oranının hesaplanmasında kullanılan ve matris boyutlarına göre değișen rastgele indeks değerleri (Saaty, 1980)

Table 3. Random index values used for calculation of consistency ratio which change according to matrix size (Saaty, 1980)

\begin{tabular}{|l|l|l|l|l|l|l|l|l|l|l|l|l|l|l|l|}
\hline $\mathrm{n}$ & 1 & 2 & 3 & 4 & 5 & 6 & 7 & 8 & 9 & 10 & 11 & 12 & 13 & 14 & 15 \\
\hline $\mathrm{RI}$ & 0.00 & 0.00 & 0.58 & 0.90 & 1.12 & 1.24 & 1.32 & 1.41 & 1.45 & 1.49 & 1.51 & 1.48 & 1.56 & 1.57 & 1.59 \\
\hline
\end{tabular}


Çizelge 4. Uygunluk sınıfları ve değerleri

Table 4. Suitability classes and their values

\begin{tabular}{lccc}
\hline Sınıf & Tanımlama & Değer & $($ FAO; 1985$) \%$ \\
\hline S1 & Çok uygun & $20423.22-25529.03$ & $80-100$ \\
S2 & Orta uygun & $17317.42-20423.22$ & $60-80$ \\
S3 & Az uygun & $13192.32-17317.42$ & $40-60$ \\
N & Uygun değil & $<13192.32$ & $0-40$ \\
\hline
\end{tabular}

ait oldukları kriterlerin öncelik vektörleriyle (ağırlık puanlarıyla) çarpılıp toplanarak, çalışma alanında ikinci ürün olarak soya yetiştirilmesine ait uygunluk değerleri hesaplanmıştır (Çizelge 4). Bu değerler FAO (1985)' e göre sınıflandırılıp, standart hale getirilerek, ikinci ürün soyaya ait uygun potansiyel alanlar haritası olușturulmuștur.

Bu değerlerin hesaplanmasında, kriterlerin aynı ölçekte birleștirilebilir yani toplanabilir hale getirilmesi için, Ağırlıklandırılmıș Doğrusal Kombinasyon yöntemine ilișkin așağıdaki eșitlik kullanılmıștır (Patrono, 1998).

$$
S=\sum_{i=1}^{n} W_{i} X_{i}
$$

\section{S: toplam puan}

$W_{i}$ : kriterin ağırlık puanı

$X_{i}$ : alt kriter uygunluk puanı

$n$ : toplam kriter sayısı

\section{Bulgular ve Tartıșma}

Öncelikle ikinci ürün olarak soyanın yetiștirilmesi üzerinde etkisi olan, ana ve alt kriterler, ürün uzmanı görüșlerine dayanarak, tespitleri yapılmıș ve daha sonra bu kriterlerin ağırlık puanları, AHS tekniğine göre hesaplanmıștır. Birinci așamada, iklim, toprak ve topoğrafya ana kriterlerinin öncelik vektörleri (ağılık puanları) hesaplanırken, 0.03 (\% 3) tutarlılık oranında tutarlı matris olarak, kriterler arası ikili karșılaștırmaları yapılmıștır (Çizelge 5). Ana kriterler için yapılan AHS tekniği hesaplamalarına göre; en yüksek öncelik vektörü (ağırlık puanı) değeri, 0.669 (\% 66.9) oranıyla iklim ana kriteri olmuștur. İklim ana kriterini sırasıyla topoğrafya (\% 26.7) ve toprak (\% 6.4) ana kriterleri izlemiștir.

Bitkisel ürünlerin yetișebilmeleri, bulundukları ortamın çevresel etkilerine bağlıdır. Bitkiler sadece çevre koşullarının

Çizelge 5. Ana kriterlerin ağırlık değerlerinin belirlenmesine yönelik AHS tekniği hesaplamaları

Table 5. Calculations of AHS technique to determine weighted values for main criteria

\begin{tabular}{|c|c|c|c|}
\hline & \multicolumn{3}{|c|}{ Ana Kriterler İkili Karșılaștırma Matrisi } \\
\hline & İklim & Toprak & Topoğrafya \\
\hline İklim & 1.000 & 9.000 & 3.000 \\
\hline Toprak & 0.111 & 1.000 & 0.200 \\
\hline \multirow[t]{3}{*}{ Topoğrafya } & 0.333 & 5.000 & 1.000 \\
\hline & \multicolumn{3}{|c|}{ Ana Kriterler Normalize Edilmiș İkili Karșılaștırmalar Matrisi } \\
\hline & İklim & Toprak & Topoğrafya \\
\hline İklim & 0.693 & 0.600 & 0.714 \\
\hline Toprak & 0.077 & 0.066 & 0.048 \\
\hline \multirow[t]{3}{*}{ Topoğrafya } & 0.231 & 0.333 & 0.238 \\
\hline & \multicolumn{3}{|c|}{ Öncelik Vektörü } \\
\hline & $\begin{array}{l}\text { Normalize Edilmiș } \\
\text { Satırlar Toplamı }\end{array}$ & $\begin{array}{l}\text { Normalize Edilmiș } \\
\text { Satırlar Ortalaması }\end{array}$ & Öncelik Vektörü \\
\hline İklim & 2.007 & $2.007 / 3$ & 0.669 \\
\hline Toprak & 0.191 & $0.189 / 3$ & 0.064 \\
\hline Topoğrafya & 0.802 & $0.801 / 3$ & 0.267 \\
\hline \multicolumn{3}{|c|}{$\lambda_{\max }: 3.029 ;$ Ri: $0.58 ;$ TO: $0,03<0.10$} & $\Sigma=1$ \\
\hline
\end{tabular}


müsaade ettiğiölçüde varlıklarını sürdürebilirler. $\mathrm{Bu}$ yüzden, bir bitkinin yetişme koşullarının incelenmesi, o yerdeki bitkinin yaşamasını sağlayan iklim, toprak ve topoğrafya gibi çevresel etkilerle doğrudan ilişkilidir. Bitkilerin bulundukları ortama adaptasyonları, iklim ve toprak şartlarına uygun olması anlamına gelmektedir ve bu durum onların olumsuz bir durum karşısında zarar görmesini en aza indirmektedir (Roberts ve ark., 1993). Çevresel etkilerin en önemlisi olan iklim, topoğrafyayı ve toprağı kontrol eden ana etmendir. Özellikle iklimin ve topoğrafyanın bitkilerin gelișimi, verimi ve kalitesi üzerinde, önemli etkisi bulunmakta olup, aralarındaki ilișkinin kurulması gerekmektedir (Bouma, 2005).

Alt kriterler için ikili karșılaștırmalar matrisi, normalize edilmiiș ikili karșılaștırmalar matrisi ve bunlara bağlı olarak öncelik vektörleri, 0.08 (\% 8) tutarlılık oranı dahilinde tutarlı bir matris olarak elde edilmiștir (Çizelge 6). Çalıșma alanında ikinci ürün soyanın yetișmesi üzerinde en fazla etkili olan alt kriterin 0.376 (\%37.6) oranıyla vegetasyon süresi olduğu tespit edilmiștir. Vegetasyon süresini sırasıyla etkili sıcaklık toplamı (0.277), Temmuz ayı ortalama sıcaklığı (0.143), Ağustos ayı ortalama sıcaklığı

Çizelge 6. Alt kriterlerin ağırlık değerlerinin belirlenmesine yönelik AHS tekniği hesaplamaları

Table 6. Calculations of AHS technique to determine weighted values for subcriteria

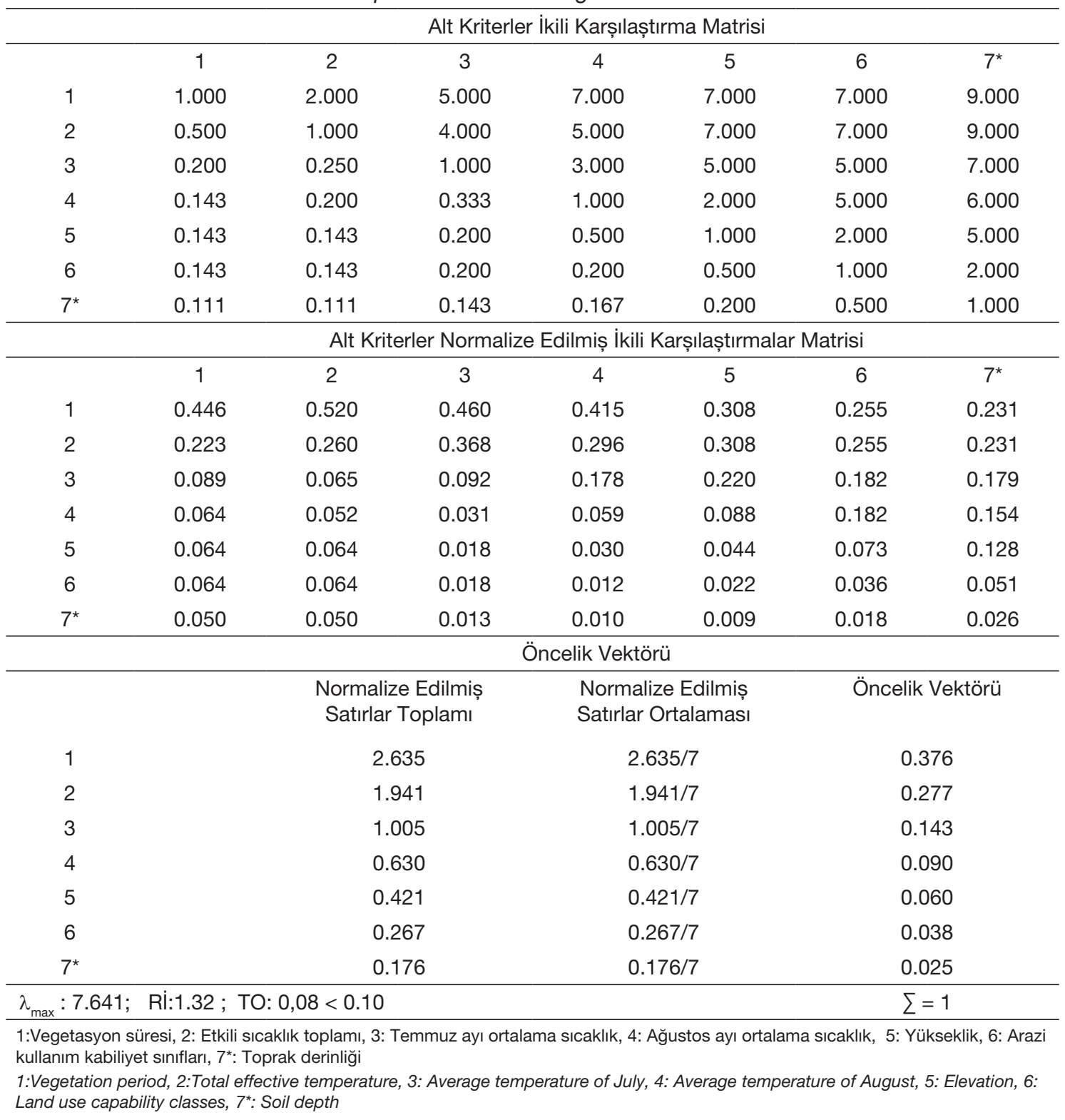


(0.090), yükseklik (0.060), arazi kullanım kabiliyet sınıfları (0.038) ve toprak derinliği (0.025) alt kriterleri takip etmiștir.

Soyanın ikinci ürün olarak yetiștirilmesindeki en önemli kıstaslardan biri, bitkinin çıkıșından itibaren hasat olgunluğuna gelene kadarki süredir. Bir alanın iklimsel olarak bu süreyi karșılayıp karșılayamaması, ikinci ürün olarak soyanın yetiștirilmesi açısından son derece önemlidir.

Üretilecek soya çeşidinin erkenci veya geççi özellikte olmasına da bağlı olarak, o çeşidin bir bölgede bașarıyla yetiștirilebilmesini etkileyen veya sınırlayabilen en önemli faktör, söz konusu bölgenin iklim özellikleridir. Kıșlık tahılların yaz ortasına doğru hasat edilmelerinden sonra, yerlerine ekilebilecek ikinci ürün bitkilerinin seçiminde de, uygun vejetasyon sürelerinin bulunup bulunmaması etkili olmaktadır. Akdeniz ve Ege Bölgelerinde, arpa ve buğday hasadının çoğunlukla Haziran ayı ortası dönemde tamamlanması nedeniyle, Haziran ayı sonuna kadar ikinci ürün soya ekilișleri için gerekli toprak hazırıkları ve sulama ișlemleri yapılabilmektedir. Tahıl hasadının gecikerek, Temmuz ayı ortalarında yapılabildiği bölgelerde ise, ikinci ürün soya tarımı için uygun bir yetișme süresi kalmamaktadır. Ülkemizin iklim șartlarına uygun ikinci ürün soya çeșitleri için yetișme süresi; hasat dönemindeki iklim uygunsuzlukları nedeniyle daha fazla uzayabildiği gibi, böcek zararı veya Kömür Çürüklüğü (Macrophomina spp.) hastalığı gibi bazı hastalıkların etkisiyle daha da kısalabilmekte ve verimleri de aynı ölçüde düșmekte olup, uygun șartlarda bu süre 90-110 gün arasında değișmektedir. $\mathrm{Bu}$ durumda, II. ve III. olgunlașma gruplarına ait erkenci ve orta erkenci soya çeșitlerinin tercihi, soyanın ikinci ürün olarak yetiștirilme șansını artırabilmektedir. (Anonim, 1985). İkinci ürün olarak soyanın vegetasyon süresi ile ilgili yapılmış çalışmalarda bu süre 80-109 (Dong ve ark., 1990), 92-109 (Mordvıntseu ve ark., 1991), 95-105 (Algan, 1990) olarak belirlenmiștir.

İkinci ürün olarak soyanın toplam sıcaklık isteği, vejetasyon süresinin belirlenmesinde etkili olan önemli bir alt parametredir. Yaz dönemi boyunca toplam olarak 2400 C $^{0}$ sıcaklığa sahip yerlerde, soya bitkisi sorunsuz olarak yetiştirilebilmektedir (ilisulu, 1973). İkinci ürün soya yetiștirilmesinde ekim ve hasat dönemleri arasında kalan süredeki toplam sıcaklık isteği, çok uygun alanlar için $2250 \mathrm{C}^{0}$, nin üzeri, orta uygun alanlar için 2000-2250 $\mathrm{C}^{0}$ arası, az uygun alanlar için 1500-2000 $\mathrm{C}^{0}$ arası ve hiç uygun olmayan alanlar için ise 1500 C'nin altında olarak esas alınmıștır.

Ülkemizde Temmuz ayı, çok geççi soya çeșitleri dıșında, ikinci ürün soya ekilișleri için çiçeklenme dönemi bașlangıcını simgelemektedir. Bu dönemdeki düșük sıcaklıklar ve uzun süreli kapalı hava, çiçek olușumunu ve döllenmeyi olumsuz etkilerken, așırı yüksek sıcaklıklar da çiçek dökmeyi artırmakta ve dolayısıyla ileriki dönemlerde daha az bakla olușumu yoluyla, verimi azaltıcı etkiler yapabilmektedir. Ağustos ayı ise, ikinci ürün soya için bakla olușumu ve baklalarda dolumun gerçekleștiği dönem olup, doğrudan verime etki eden bir dönemdir. Temmuz ve Ağustos aylarında bitkinin toplam sıcaklık isteğinin yarısının $\left(1500 \mathrm{C}^{0}\right)$ bu iki ay boyunca karșılanmasından dolayı, aylık ortalama sıcaklık değerleri $25 \mathrm{C}^{0}$ ve üzeri sıcaklıklara sahip yerler için çok uygun, 22-25 $\mathrm{C}^{0}$ arasındaki yerler için orta uygun, 20-22 $\mathrm{C}^{0}$ olan yerler için az uygun ve $20 \mathrm{C}^{0}$ 'den düșük aylık ortalama sıcaklığa sahip yerler için ise hiç uygun olmayan alanlar olarak belirlenmiștir.

Genel olarak yüksekliği 2000 metrenin altındaki alanlarda soyanın yetiștirilebileceği bilinse de, 1000 metrenin altındaki yükseklik değerleri, soya tarımı için daha uygun kabul edilmektedir. Ülkemizde soyanın en fazla ekim alanı bulduğu yerlerin, genellikle rakımı düșük sahil ovaları olduğu düșünüldüğünde, bu çalıșmada; ikinci ürün soyanın çok uygun alanlar için intiyaç duyduğu yükseklik değeri 0-600 m, orta uygun alanlar için 600-800 m, az uygun alanlar için 800-1100 m ve hiç uygun olmayan alanlar için ise $1100 \mathrm{~m}$ ve üzeri olarak belirlenmiștir.

İkinci ürün soya tarımında, bitki boyu ve kök uzunluğu, ana ürün soyaya göre daha kısa kalsa da, derin toprakların bitki yetiștiriciliğindeki önemi, sığ topraklara göre çok daha fazladır.

Çalışma alanındaki araziler, kullanım kabiliyetlerine göre, üzerinde tarım yapılabilen 


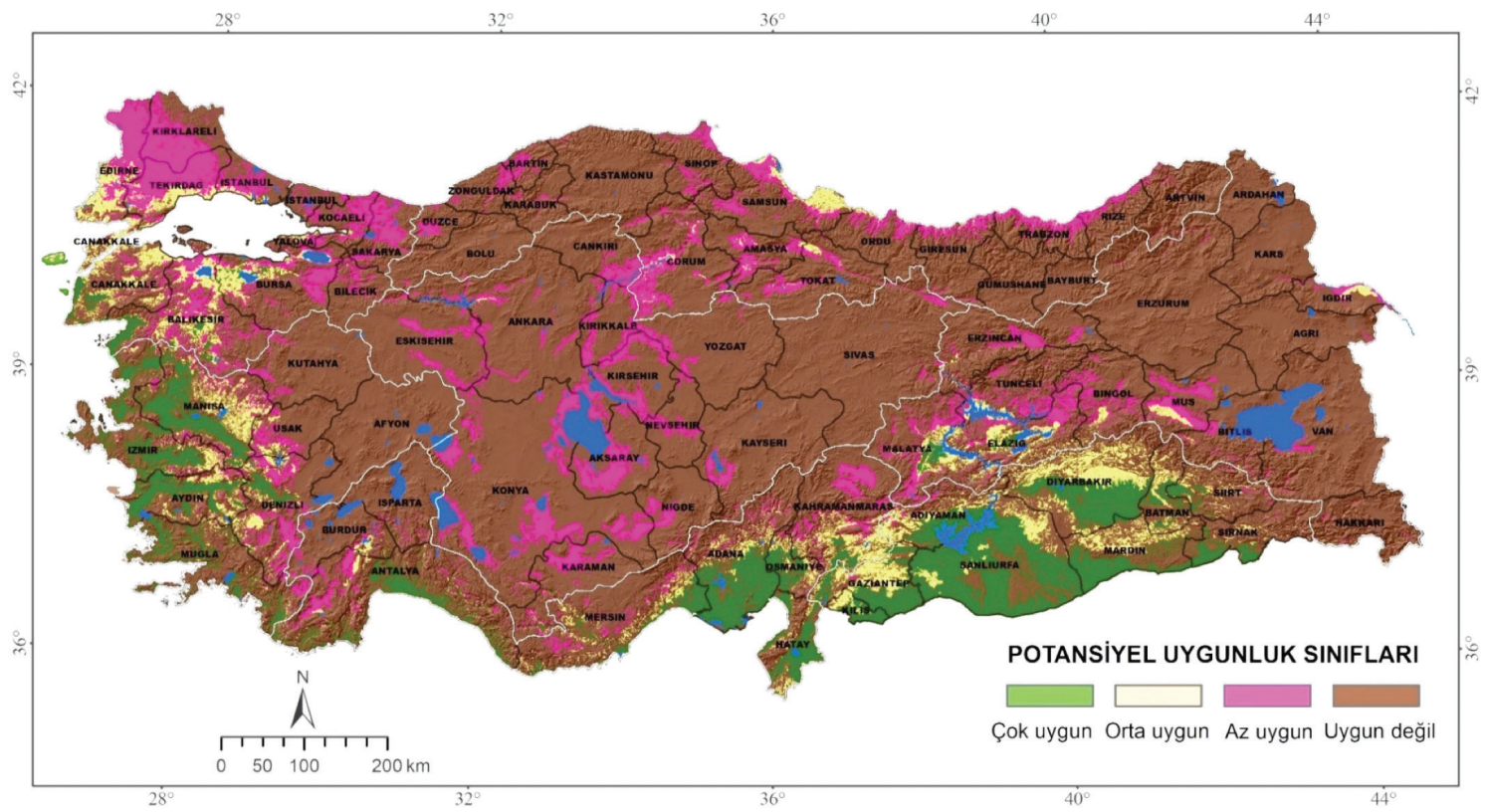

Șekil 3. Türkiye'de ikinci ürün soya yetiștirmeye uygun potansiyel alanlar haritası

Figure 3. Potential suitable areas map for double crop soybean cultivating in Turkey

I. sınıf araziler ile hiç bir șekilde tarıma elverișli olmayan ve sadece doğal hayata ortam teșkil edebilen VIII. sınıf araziler arasında sınıflandırılmıștır (Anonim, 2008). Bu arazi kullanım kabiliyet sınıfları, ikinci ürün soyanın yetiștirilmesine yönelik yapılan bu planlama çalıșmasında, ürünün arazi istekleri arasında bir alt kriter olarak değerlendirilmiștir. İkinci ürün soya açısından çok uygun ve orta uygun alanlar için I. sınıf tarım arazileri, az uygun alanlar için II. sınıf tarım arazileri, uygun olmayan alanları için ise III ile VIII. sınıf arasındaki tarım arazileri eşik değerler olarak değerlendirilmiştir.

İkinci ürün soyanın ihtiyaç duyduğu ana ve alt kriterler, hesaplanan ağırlık değerleri oranında, ağırıklandırılmıș doğrusal kombinasyon yöntemine göre birleștirilmiș ve ürüne ait uygun potansiyel alanlar haritası elde edilmiștir (Șekil 3).

Uygunluk sınıflarının bölgeler bazında alansal ve oransal dağılımları göz önüne alındığında; ikinci ürün olarak soyanın çok uygun sınıfta (S1) yetiștirilebileceği alanlar, \% 37.74 oranında 2896556.13 hektarlık alan ile en fazla Güneydoğu Anadolu Bölgesi olmuştur. Bu bölgeyi \% 15.68 (1 406042.48 hektar) oranında Akdeniz Bölgesi ve \% 15.33 (1 366474.71 hektar) oranında ise Ege Bölgesi takip etmektedir. Özellikle bölgeler arasındaki etkili sıcaklık toplamı ve yükseklik farklarının kısıtlayıcı etkilerine bağlı olarak, ikinci ürün olarak soyanın yetişmesinde uygun olmayan (N) alanların dağılımında, İç Anadolu Bölgesi 16671737.69 hektar alan ile en fazla alan olarak hesap edilmiștir. Bunu 13717071.50 hektar alan olarak, Doğu Anadolu Bölgesi ve 10460478.34 hektar alanla da Karadeniz Bölgesi takip etmektedir (Çizelge 7).

$\mathrm{Bu}$ uygunluk sınıflarının çalıșma alanı içerisindeki genel dağılımlarında; alanın \% 7.65'nin (5 968013.35 hektar) çok uygun (S1), \% 4.70'nin ( 3666170.55 hektar) orta uygun (S2), \% 8.43'nün (6 584410.16 hektar) az uygun (S3) ve \% 79.22'sinin (61 839407.74 hektar) ise uygun olmayan (N) sınıfta yer aldığı tespit edilmiștir.

\section{Sonuçlar}

Ülkemizde, ikinci ürün soya yetiştirmeye uygun potansiyel alanların belirlenmesi amacıyla yürütülen bu çalıșmada, elde edilen uygunluk haritası incelendiğinde; Akdeniz, Ege ve Güneydoğu Anadolu Bölgelerindeki ovaların, ikinci ürün soya için en uygun alanlar olarak çıktığı görülmektedir. Soya üretim alanlarının çalıșma alanı içerisindeki dağılımlarında vegetasyon süresi, TemmuzAğustos ayları ortalama sıcaklıkları ve yükseklik 
Çizelge 7. İkinci ürün soya yetiștirilmesi için potansiyel uygunluk sınıflarının bölgeler bazında alansal ve oransal dağılımları

Table 7. Areal and proportional distributions of potantional suitability classes for double crop soybean cultivation on regional basis

\begin{tabular}{|c|c|c|c|c|}
\hline \multirow[b]{2}{*}{ BÖLGELER } & \multicolumn{4}{|c|}{ UYGUNLUK SINIFLARI } \\
\hline & $\begin{array}{l}\text { Çok Uygun } \\
\text { (S1) }\end{array}$ & $\begin{array}{l}\text { Orta Uygun } \\
\text { (S2) }\end{array}$ & $\begin{array}{l}\text { Az Uygun } \\
\text { (S3) }\end{array}$ & $\begin{array}{l}\text { Uygun Değil } \\
(\mathrm{N})\end{array}$ \\
\hline Akdeniz Bölgesi & $\begin{array}{c}1406042.48 \\
\% 15.68\end{array}$ & $\begin{array}{c}499568.90 \\
\% 5.58\end{array}$ & $\begin{array}{c}460620.82 \\
\% 5.14\end{array}$ & $\begin{array}{c}6596898.94 \\
\% 73.6\end{array}$ \\
\hline Doğu Anadolu Bölgesi & $\begin{array}{c}77472.61 \\
\% 0.5\end{array}$ & $\begin{array}{c}397305.66 \\
\% 2.66\end{array}$ & $\begin{array}{c}798177.97 \\
\% 5.33\end{array}$ & $\begin{array}{c}13717071.50 \\
\% 91.51\end{array}$ \\
\hline Ege Bölgesi & $\begin{array}{c}1366474.71 \\
\% 15.33\end{array}$ & $\begin{array}{c}493877.23 \\
\% 5.54\end{array}$ & $\begin{array}{c}426110.89 \\
\% 4.78\end{array}$ & $\begin{array}{c}6625081.50 \\
\% 74.35\end{array}$ \\
\hline Güneydoğu Anadolu Bölgesi & $\begin{array}{c}2896556.13 \\
\% 37.74\end{array}$ & $\begin{array}{c}1141473.23 \\
\% 14.87\end{array}$ & $\begin{array}{c}31730.98 \\
\% 0.4\end{array}$ & $\begin{array}{c}3604955.03 \\
\% 46.97\end{array}$ \\
\hline Karadeniz Bölgesi & $\begin{array}{c}0.00 \\
\% 0.00\end{array}$ & $\begin{array}{c}209133.69 \\
\% 1.79\end{array}$ & $\begin{array}{c}1062209.63 \\
\% 9.05\end{array}$ & $\begin{array}{c}10460478.34 \\
\% 89.16\end{array}$ \\
\hline İç Anadolu Bölgesi & $\begin{array}{c}8500.80 \\
\% 0.05\end{array}$ & $\begin{array}{c}14739.30 \\
\% 0.08\end{array}$ & $\begin{array}{c}1870795.14 \\
\% 10.08\end{array}$ & $\begin{array}{c}16671737.69 \\
\% 89.79\end{array}$ \\
\hline Marmara Bölgesi & $\begin{array}{c}212966.62 \\
\% 2.95\end{array}$ & $\begin{array}{c}910072.54 \\
\% 12.61\end{array}$ & $\begin{array}{c}1934764.73 \\
\% 26.79\end{array}$ & $\begin{array}{c}4163184.74 \\
\% 57.65\end{array}$ \\
\hline Alan (ha) & 5968013.35 & 3666170.55 & 6584410.16 & 61839407.74 \\
\hline Oran (\%) & $\% 7.65$ & $\% 4.70$ & $\% 8.43$ & $\% 79.22$ \\
\hline
\end{tabular}

kriterlerinin, en önemli sınırlayıcı etkiye sahip olduğu görülmektedir. Özellikle İkinci ürün soyada 110 gün civarında bir yetișme süresine intiyaç duyulması, soya ekim alanlarının çok uygun sınıfındaki dağılımını önemli ölçüde sınırlandırmıștır.

Çalışma alanı bölgesel olarak incelendiğinde; günümüzde de en fazla soya üretiminin gerçekleștirildiği yer olarak bilinen Çukurova Bölgesinin, yükseklik kriterinin sınırlayıcı etkisi altında kalmayan geniș ovalarının tamamında, buğday ve arpa hasadının ardından ikinci ürün soya için çok uygun alanlar olarak görülmektedir. Sulama imkanı açısından problem yașanmayan Çukurova'da, ikinci üründe $350-400 \mathrm{~kg} \mathrm{da}^{-1}$ verim seviyelerinin alınabilmesi, Çukurova Bölgesini ikinci ürün soya açısından önemli bir alan haline getirmektedir.

Güneydoğu Anadolu Bölgesi, iklim uygunluğu ve daha geniș ovalara sahip olması sayesinde, ikinci ürün soya için Çukurova'dan 4-5 kat daha fazla bir potansiyel üretim alanı sunmaktadır.
Ege Bölgesinde, bașta kıyı ovaları olmak üzere bölgenin büyük bir kısmında, tahıl hasadının yaz bașında tamamlanmasıyla, ikinci ürün soya tarımına geçilebilmesi mümkün görülmektedir. Diğer 4 bölgede ise (Marmara Bölgesi, İç Anadolu Bölgesi Karadeniz Bölgesi ve Doğu Anadolu Bölgesi), ikinci ürün soya için çok uygun sınıfına girebilecek alanların pek bulunmaması, bunun yanında çok az miktarda orta uygun sınıfındaki alanların görülmesi, bu bölgelerde ikinci ürün soya potansiyelinin olmadığını belgelemektedir.

Sonuç olarak, Akdeniz, Ege ve Güneydoğu Anadolu Bölgelerindeki çok uygun ve orta uygun alanlar ile, sulama imkanlarının olması durumunda Marmara Bölgesinin orta ve güneyinde yer alan ovaların orta uygun sınıfında çıkması, ikinci ürün soya tarımına en elverișli alanlar olabileceğini göstermiștir.

Bu alanların, ülkemiz tarımına ve özellikle de sulu tarıma en uygun ovaları içermesi, bu alanlarda sadece soya değil, pek çok tahıl, endüstri bitkisi, sebze ve meyve ürünlerini de pay sahibi kılmaktadır. 
Ülkemizde ana ürün buğday sonrası ekimi yapılan ikinci ürün soyanın, yerli soya üretimimizin yaklașık 2/3'ünü karșıladığı düșünüldüğünde, ikinci ürün soya üretimi için 300-350 bin hektarlık bir alanın bile yeterli olabileceği hesaplanabilir.

Çalıșma alanındaki çok uygun alanların, özellikle de sulama imkanına sahip olan bölümlerinde, yerli soya üretimi için gerekli ekim alanlarının sağlanması adına üretim desteklerine devam edilmesi durumunda, beklenen üretim artıșlarını geçekleștirebilmek mümkün olabilecektir. Bu durumda, yaklașık 6 milyon hektarlık çok uygun sınıfında yer alan alanların 1/20'sinin ikinci ürün soyaya ayrılması sağlanabilirse, ithalata gerek duyulmadan, yerli üretimle tüm soya intiyacımızın karșılanabilmesi de gündeme gelebilecektir.

\section{Kaynaklar}

Algan, N. (1990). Ege Bölgesi, koșullarında bazı soya hat ve çeșitlerinin adaptasyon yetenekleri üzerinde araștırmalar. Ege Üniversitesi Ziraat Fakültesi Dergisi. 27 (2), 33-47.

Anonim, (1985). Soya Çeșitleri ve Özellikleri. Akdeniz Tarımsal Araștırma Enstitüsü Yayını 5, 1-2.

Anonim, (2008). Toprak Arazi Sinıflaması Standartları Teknik Talimati ve Illgili Mevzuat http://www.tarim.gov.tr/Belgeler/Mevzuat/ Talimatlar/Toprak Arazi Siniflamasi Standartlari Teknik Talimati ve Ilgili Mevzuat Erișim Tarihi : 04.05.2018

Arıoğlu, H. (2013). Soya Tarımı. Çukurova Üniversitesi Ziraat Fakültesi, Tarla Bitkileri Bölümü, Adana.

Armacost, L.R., Componation, P.J., Mullens, M.A., \& Start, W. (1994). An AHY framework for prioritizing customer requirements in QFD: an industrialized housing application, IIE Transactions, 26 (4), 72-79.

Bagli, S.,Terres, J.M., Gallego, J., Annoni, A., \& Dallemand, J.F. (2003). Agro-PedoClimatological Zoning of Italy. Monograph 20550 EN - @ E European Communities, Printed in Italy.

Bhermana, A., Sunarminto, B.H., Utami, S.N.H.,\& Gunawan, T. (2013). The Combination of Land Resource Evaluation Approach and Gis Applicatıon to Determine Prime Commodities for Agricultural Land Use Planning at Developed Area (A Case Study Of Central Kalimantan Province, Indonesia). ARPN Journal of Agricultural and Biological Science 8 (12), December.

Bouma, E. (2005). Development of comparable agroclimatic zones for the international exchange of data on the efficacy and crop safety of plant protection products, OEPP/EPPO Bulletin, 35 , 233-238.

Büyükyazıcı, M. (2000). Analitik Ağ Süreci, Bilim Uzmanlı̆̆ı Tezi, Hacettepe Üniversitesi Fen Bilimleri Enstitüsü İstatistik Anabilim dalı, Ankara.

Dengiz, O., \& Sarıoğlu, F.E. (2013). Arazi Değerlendirme Çalıșmalarında Parametrik Bir Yaklașım Olan Doğrusal Kombinasyon Tekniği. Tarım Bilimleri Dergisi.19, 101-112.

Dong, Z., Dong, J.G., \& QIIJ, B.W. (1990). Studies On Growth Development and Yield Component of Early Maturity Soybean In Northeas China.I Some Characteristics of Growth and Early Maturity Soya Beans. Soybean Science, Shenyang Agricultural Universty Lianoning, 9(4), 265-270, China.

Engin, M., \& Arığlu, H.H. (1982). Soyanın Gübrelenmesi ve Bakteri Așılanması. Çukurova Bölgesi' nde Soya Üretimi ve Sorunları Semineri Bildirisi, Hatay.

Farr, T.G., \& Kobrick, M. (2000). Shuttle radar topography mission produces a wealth of data, EOS Transactions AGU, 81, 583-585.

He, W., Yang, S., Guo, R., Chen, Y., Zhou, W., Jia, C., ... Sun, G. (2011). Gis- Based Evaluation of Soybean Growing Areas Suitability in China. Part III. International Federation for Information Processing AICT 346, 357-366.

Herridge, D.F. \& Danso, S.K.A. (1995). Enhancing crop legume N2 fixation through selection and breeding, Plant Soil, 174, 51-82.

Hutchinson, M.F. (1995). Interpolating mean rainfall using thin plate smoothing splines. Int. J. Geogr. Info. Systems 9, 385-403.

İlisulu, K. (1973). Yağ Bitkileri ve Islahı,192,İstanbul.

Malczewski, J. (2004). GIS-based land-use suitability analysis: a critical overview. Progress in Planning, 62 (1),3-65.

Malczewski, J. (2006). Ordered weighted averaging with fuzzy quantifiers: GIS-based multi criteria evaluation for land-use suitability analysis.International Journal of Applied Earth Observation and Geoinformation, 8 (4), 270-277.

Manuel, P.C., Huelges, R.R., \& Espanto, L.H. (1988). Adaptation of soybean in lupano. Nueva, Ecia the Philipinnes.

Martz, L.W., \& Garbrecht, J.(1992). Numerical definition of drainage network and subcatchment areas from digital elevation models, Computers and Geosciences, 18 (6), 747 - 61.

Mendas, A., Hamadouche, M.A., Nechniche, H., \& Djilali, A. (2007). Elaboration d'un systèmed'aide a' la décisionspatiale. Application a' la dangerosité de l'infrastructureroutière", Journal of Decision System, 16 (3), 369-391.

Mendas, A., \& Delali, A. (2012). Integration of MultiCriteria Decision Analysis in GIS to develop land suitability for agriculture.Application to durum wheat cultivation in the region of Mleta in Algeria. Computers and Electronics in Agriculture, 83, 117-126. 
Mordvıntseu, M.P., Sokolov, S.M., Vizner, V.S., \& Latukhin, A.P. (1991). Early Soybean Varieties Soerl. Seletsia: Semenovodstua (Moskova), 3, 35-36 (Ru) Opytnaya Stanstiya Oroshaemogo Zemledeliya, Ershow, USSR.

Mounts, T.L., Wolf, W.J., \& Martinez, W.H. (1987). Processing and Utilization. In Soybeans: Improvement, Production, and Uses, Second Edition, J.R. Wilcox, 1987, Madison,Wisconsin, USA.

Patrono, A. (1998). Multi-Criteria Analysis and Geographic Information Systems: Analysis of Natural Areas and Ecological Distributions. Multicriteria Analysis for Land-Use Management, Edited by Euro Beinat and Peter Nijkamp, Kluwer Academic Publishers, Environment and Management, 9, 271- 292, AA Dordrecht, The Netherlands.

Pertziger, F., \& De Pauw, E. (2002). CLIMAP. An Excel-based software for climate surface mapping. ICARDA, Aleppo, Syria.

Prakash, T.N. (2003). Thesis (MSc), Land suitability analysis for agricultural crops: a fuzzy multicriteria decision making approach. (ITC) International Institute for Geoinformation Science and Earth Observation, Enschede, The Netherlands.
Roberts, E., Summerfield, R., Ellis, R., \& Qi, A. (1993). Adaptation of flowering in crops to climate.Outlook Agric. 22, 105-110.

Saaty, T.L. (1980). The Analytıc Hierarchy Process, ISBN 0-07-054371-2, USA.

TUIK, (2015). http://www.tuik.gov.tr (Erișim Tarihi : 06.06.2018)

Türkeș, M., Sümer, U. M., \& Çetiner, G. (2000). 'Küresel iklim değișikliği ve olası etkileri', Çevre Bakanlığı, Birleșmiș Milletler İklim Değișikliği Çerçeve Sözleșmesi Seminer Notları (13 Nisan 2000, İstanbul Sanayi Odası), 7-24, ÇKÖK Genel. Müdürlüğü., Ankara.

Yılmaz, E., Ok, K., \& Okan,T. (2004). Ekoturizm Planlamasında Katılımcı Yaklașımla Etkinlik Seçimi. Cehennemdere Vadisi Örneği. T.C. Çevre ve Orman Bakanlığı, Doğu Akdeniz Ormancilık Araștırma Müdürlüğü, Çevre ve Orman Bakanlığı Yayın 237, DOA Yayın 30, Teknik Bülten 21, 56, Tarsus. 